\title{
Agronomic benefits of long-term trials
}

\author{
M. JolÁNKAI, Á. TARnAWA, H. F. NyÁRAI, Z. SZENTPÉTERY, M. K. KASSAI \\ Crop Production Institute, Szent István University, Gödöllő, Hungary
}

\begin{abstract}
Long-term trials are established in order to explore and observe plant and soil interrelationships in situ. Long-term trials can be described as live instruments providing ceteris paribus conditions in temporal sequences.

This review provides an introduction to major long-term trials in Hungary and in other parts of the world. It gives a brief summary of the origins of plant nutritional research, beginning with some data from Homer and the willow tree experiment of van Helmont, as well as the discovery of physiological processes by von Liebig, Lawes and Boussingault. The most profound long-term trials, like the Orto Botanico in Padova, the Linné Garden in Uppsala and the Broadbalk in Rothamsted are presented in the paper.

The agronomic, educational and scientific benefits of the major Hungarian long-term trials are also discussed, from Westsik (1929) to Martonvásár and the National Plant Nutrition Trials (OMTK) set up in 1963. There is a list of experimental sites giving information on the most important recent long-term trial locations and their activities.
\end{abstract}

Key words: long-term trials, plant nutrition, crop physiology, adaptability

\section{Roots}

Field trials in general and long-term trials in particular are established in order to explore and observe plant and soil interrelationships in situ. Long-term trials can be described as live instruments providing ceteris paribus conditions in temporal sequences (KELLOGG 1957). The utility of such trials is in their exact layout and the length of period they are operated. Simply, the older the better regarding the mathematical plausibility of such scientific instruments (JOLÁNKAI 2017).

The first written information on manure dates back to almost three millennia. Homer $\left(11^{\text {th }}\right.$ century BC) presents a story in the Odyssey about the homecoming of Odysseus to Ithaka, when he is recognized by his old dog “... lying on a heap of dung with which the thralls were wont to manure the land". Homer's description of this agronomic measure provides evidence that the people of his time knew about the fertilising value of animal excreta, the collection and storage of this material, and the means of dispensing it in the fields.

The fabulous initial willow tree experiment of van Helmont was recorded in 1635. It was the first scientific plant analytical approach to detecting the physiology

Postal address: MÁRTON JOLÁNKAI, Crop Production Institute, Szent István University,

Gödöllő, Páter Károly u 1.

E-mail: jolankai.marton@mkk.szie.hu 
of plant growth. A young willow tree of known weight was placed in a pot containing a measured amount of soil. The pot's surface was sealed to prevent any alien material from reaching the soil surface. Then water was applied regularly to the system over two years. At the end of the trial, precise measurements were made. Van Helmont stated that there was a significant growth and development of the willow tree, and since there were no major differences in the soil data (he assumed that the few ounces lost could be due to measurement errors) he concluded that the only material source of life is water alone. Although the experiment led to no plausible results, it can be regarded as the dawn of a new era.

The development of chemistry and a period of almost two centuries were needed for the discovery of physiological processes by von Liebig, Lawes and Boussingault. Justus von Liebig described the level of development with the help of a barrel where the staves were uneven in size. According to his theory, plant growth is determined by the minimum level of a certain plant nutrient. His theory was clear and became widely known, but was immediately doubted by Sir John Bennet Lawes, who carried out a replicated exact field experiment but could not verify the theory. Who was right and who was wrong? Both of them were right; the discrepancies were caused by how they approached the problem. Liebig, as a chemist, followed a static model, while Lawes, as a practising landlord, made a dynamic assessment (the proof of the pudding is in the eating). A third person and a new discovery was needed to formulate the physiological process. Jean Baptiste Boussingault was the man who first described the nitrogen cycle and so gave an explanation of the diverse results. It was also at this time that an urgent need was felt to establish exact field trials to provide in vivo conditions for research in plant physiology.

\section{Historical long-term trials}

The first long-term trials were not established by agriculturists, but by botanists. The basic task of these trials was to provide "ceteris paribus" (equal measures) conditions for scientific observations. It had long been known that identical conditions and replicated methods were needed to study the behaviour, growth and development of any living creature (CSERHÁTI 1901). It is difficult to identify which trial can be said to be the first in the world, because there are at least a dozen candidates for this title. It may also be difficult to define what constitutes a trial, and what we mean by long-term. From the point of view of plant growth physiology the oldest long-term trial is probably the Orto Botanico in Padova, set up in 1545 , where various plant species have since been tested under rainfed and irrigated conditions in a controlled system.

Another long-term trial somewhat similar to this, was the Linné Garden in Uppsala, established in 1728. Carolus Linné was a botanist, and he was keen to exclude environmental effects that might cause changes in plant morphology, so he set up a design for parallel observations. The Linné Garden is no longer in operation; it is a sort of live museum of science maintained by the local community. 
The oldest long-term trial dealing with plant nutrition as well as monocropping problems is the Broadbalk in Rothamsted. Sir John Bennet Lawes, an English nobleman, entrepreneur and agricultural scientist, established it in 1843, aiming among other things to clarify plant nutrition principles. He was the man who employed Joseph Henry Gilbert, with whom he developed superphosphate fertiliser. He founded an experimental farm at his home in Rothamsted Manor, which eventually became the Rothamsted Experimental Station, one of the most renowned scientific research institutions in agriculture.

\section{Long-term trials in Hungary}

Hungary has always been a land dedicated to agricultural activities and thus to agronomic research. For historical reasons most of the $19^{\text {th }}$ century trials did not survive. Long-term trials in Hungary were set up to explore various scientific hypotheses and to observe agronomic techniques (VÁRALLYAY 2006, LÁNG et al. 2007, BERZSENYI and ÁRENDÁS 2009). The oldest site, maintained since 1929, is the Westsik long-term trials in Nyíregyháza. It was set up by Vilmos Westsik to study agronomic methods suitable for sandy soils. The trial has introduced various crop rotation systems. The main problem of the region is twofold: water scarcity and poor soil properties.

The Martonvásár trials were initiated by Professor Béla Györffy in 1958, the main purpose being to compare plant nutrition and crop rotation, manure and chemical fertiliser in relation to the variety-specific reactions of field crops. The trials were designed in a polyfactorial structure with replications.

The National Plant Nutrition Trials (OMTK), set up in 1963, were designed to gain reliable data on the mineral fertilization of field crops in all regions of Hungary. The experimental network was initiated by Professor Géza Láng with the active participation of Béla Debreczeni, József Antal and Ernő Bocz.

During the past half century several crop production and soil tillage trials have been established in order to gain a better understanding of crop physiological processes within given agro-environments. Valuable results were obtained in fields such as yield quantity and quality, abiotic and biotic stress tolerance, soil pollution and remediation, and climate change phenomena.

Long-term trials are not only scientific curios or honoured relics of a museum, but highly valuable live ecological models that can never be replaced or restarted once they are terminated. These trials provide valuable, dynamic databases for solving scientific problems.

Long-term trials are therefore "major tools" for basic research on crop science, agro-chemistry, soil science and agro-ecology. Their role is similar to that of manmade tools, instruments or implements, such as phytotrons, lysimeters, hydroponics or reactors. 
Table 1

Main data of registered Hungarian national long-term trials, 2017 (Source: KISMÁNYOKY and JOLÁNKAI 2017)

\begin{tabular}{|c|c|}
\hline Location, number of long-term trials and main topics & Established \\
\hline $\begin{array}{l}\text { Nyíregyháza } 3 \\
\text { Topics: crop rotation, plant nutrition, }\end{array}$ & 1929 \\
\hline $\begin{array}{l}\text { Fülöpszállás } 1 \\
\text { Topics: crop rotation, plant nutrition }\end{array}$ & 1982 \\
\hline $\begin{array}{l}\text { Keszthely } 12 \\
\text { Topics: complex agronomy, plant nutrition, crop species and } \\
\text { varieties }\end{array}$ & 1963 \\
\hline $\begin{array}{l}\text { Debrecen (Látókép, Hajdúböszörmény) } 6 \\
\text { Topics: complex agronomy, plant nutrition, irrigation, crop } \\
\text { species and varieties }\end{array}$ & 1967 \\
\hline $\begin{array}{l}\text { Iregszemcse, Bicsérd } 2 \\
\text { Topics: Plant nutrition, crop rotation }\end{array}$ & 1967 \\
\hline $\begin{array}{l}\text { Karcag } 3 \\
\text { Topics: Plant nutrition, crop species and varieties, agronomic } \\
\text { impacts, lysimeter trials }\end{array}$ & 1984 \\
\hline $\begin{array}{l}\text { Szarvas } 1 \\
\text { Topics: Crop rotation, plant nutrition }\end{array}$ & 1989 \\
\hline $\begin{array}{l}\text { Kompolt } 2 \\
\text { Topics: Plant nutrition, energy cropping }\end{array}$ & 1967 \\
\hline $\begin{array}{l}\text { Gödöllő (Józsefmajor, Nagygombos) } 3 \\
\text { Topics: Plant nutrition, soil tillage, complex agronomy }\end{array}$ & 1972 \\
\hline $\begin{array}{l}\text { Nagyhörcsök } 6 \\
\text { Topics: Plant nutrition, agronomic impacts }\end{array}$ & 1967 \\
\hline $\begin{array}{l}\text { Őrbottyán } 2 \\
\text { Topics: Plant nutrition, agronomic impacts }\end{array}$ & 1959 \\
\hline $\begin{array}{l}\text { Nyírlugos } 1 \\
\text { Topics: plant nutrition }\end{array}$ & 1962 \\
\hline $\begin{array}{l}\text { Martonvásár } 15 \\
\text { Topics: plant nutrition, species and varieties, agronomic impacts }\end{array}$ & 1958 \\
\hline
\end{tabular}




\section{Agronomic benefits of long-term trials}

Long-term trials are established basically to clarify technical problems and to provide answers to biological and physiological questions.

As highlighted above, the aim and tasks of these trials varied, but there were two common characteristics: firstly, all of them were established in a scientifically designed layout, and secondly they all provide information to scientists as well as to practical farmers.

Most of the long-term trials are permanently open to visitors and provide a ground for extension services in the form of open days.

\section{Benefits of long-term trials in education}

In addition to their scientific value and utility, long-term trials play a major role in education. Various branches of education, including undergraduate and $\mathrm{PhD}$ courses, vocational training and extension services, may benefit from the research results obtained from long-term trials. Some of today's long-term trials were originally designed for educational purposes, such as the Westsik trial in Nyíregyháza, which demonstrates tillage methods for sandy soil to farmers. Other long-term trials were designed to solve specific scientific problems, but most of them can also be used for educational purposes. All the long-term trials in Hungary, whether owned and operated by research institutions or universities, are involved in one or more accredited educational programme. They can also be visited and studied within the framework of regular scientific and extension programmes.

\section{Economic contribution}

Long-term trials may have a role in the implementation of certain economic processes, as well as in the prevention or handling of hazards and disasters. Without the databases of long-term trials most crop production technologies and plant protection applications would be less efficient. Long-term trials may also help us to adapt international research results, materials, instruments and technologies to local conditions more efficiently. Long-term trials often contribute to avoiding or managing the consequences of natural hazards, catastrophes, climatic extremes, anomalies, epidemics, etc. (e.g. flood, water logging, drought, eutrophication, cyanide pollution, red sludge disaster), just to mention some of those encountered in recent years. Environmental protection and nature conservation should be based on long-term trials. Over $80 \%$ of the territory of Hungary is covered by terrestrial ecosystems, the vast majority of which are agro-ecosystems, a situation that is unique in Europe.

\section{Key to international cooperation}

Hungarian long-term trials represent a virtual network and most of them have a role in national programmes. They also provide the basis for regional cooperation. 
Within the Carpathian Basin many transfrontier collaborations are based on research activities in long-term trials. The research results contribute to solving problems in the fields of natural and social sciences. Some examples of this are joint research programmes involving Keszhely (Hungary) and Nitra (Slovakia), Látókép-Nyíregyháza (Hungary) and Livada (Romania) or Nagyhörcsök (Hungary) and Eszék (Croatia) or the utilization of the OMTK (National Fertilization Longterm Trials) results and data in EU climate change research projects (JOLÁNKAI 2008).

The Alps-Adria scientific cooperation provides a scientific forum for presenting and discussing the research results obtained in long-term trials in the region. At these conferences more than a thousand scientific papers have been presented during the past decade, around 200 of which were based on long-term trials (JOLÁNKAI 2009). International cooperation in this field is extremely valuable and will continue to contribute to plant and soil research in the future.

\section{Acknowledgements}

This paper presents research results gained from a long-term trial supported by TÁMOP, NVKP and VKSZ funds from the Government of Hungary.

\section{References}

BERZSENYI Z. - ÁRENDÁS T., 2009. The importance of long-term trials in the development of crop production. MTA Mezőgazdasági Kutatóintézete, Martonvásár. (In Hungarian)

CSERHÁti S., 1901. General and Specific Crop Production Czéh Sándor Könyvnyomdája, Magyaróvár. (In Hungarian)

JoláNKAI M., 2017. Agronomic benefits of long term trials. In: MAKÁDI M. (ed.) International Conference of Long Term Field Experiments "LOTEX 2017". University of Debrecen, Research Institute of Nyíregyháza. (Abstract) pp. 43.

JOLÁNKAI M., 2008. Ecosystems influenced by humans (Crop production conditions, Field crop production, Pests, diseases and weeds, Adaptation opportunities and suggestions) In: HARNOS Z. - GAÁL M. - HUFNAGEL L. (eds.). Klímaváltozásról mindenkinek. Budapesti Corvinus Egyetem. Budapest. 89-129 pp. (In Hungarian)

JoláNKAI M., 2009. Alps-Adria Scientific Cooperation - a regional forum for agricultural research. Magyar Tudomány. 170. 4. 485-489. (In Hungarian)

KellogG, C. E., 1957. We seek, we learn. In: StefFerud A. (ed.) Soil. The Yearbook of Agriculture 1957. USDA, Washington DC.

KISMÁNYOKY T. - JOLÁNKAI M., 2009. Hungarian long-term trials In: DEBRECZENI B-né - NÉMETH T. (eds.). Az Országos Mütrágyázási Tartamkísérletek (OMTK) kutatási eredményei (1967-2001). Akadémiai Kiadó, Budapest. 25-34 pp. (In Hungarian) 
KISMÁNYOKY T. - JOLÁNKAI M., 2017. A survey of long-term trials in Hungary. Report for the Government. Hungarian Academy of Sciences, Budapest (In Hungarian)

LÁNG I. - LAZÁNYI J. - CSÉP N., 2007. Joint International Conference on Longterm Experiments, Agricultural Research and Natural Resources. Centre of Agricultural Sciences, University of Debrecen, Debrecen.

VÁRALLYAY, G., 2006. Soil degradation processes and extreme soil moisture regime as environmental problems in the Carpathian Basin. Agrokémia és Talajtan. 55. (1-2) 9-18. 